\section{THE DAY AFTER THE DISASTER: A REPORT FROM A JAPANESE DISASTER MEDICAL ASSISTANCE TEAM}

\section{To the Editor}

On March 11, 2011, at 2:46 PM, Japanese time, a massive 9.0 magnitude earthquake struck off the Pacific coast of Japan's Tohoku region. The maximum seismic intensity, level 7, was recorded in Kurihara City, northwestern Miyagi Prefecture. About 25 minutes after the earthquake, enormous tsunami waves began pounding the Pacific coastline of the Tohoku region, causing massive damage to several coastal towns. This was the first mega-disaster in which modern cities were struck by a massive tsunami. As of April 6, the National Police Agency ${ }^{1}$ reported the total number of fatalities attributed to this disaster nationwide at 15676 , with 4832 people missing and 5712 people injured. The damage was the worst in Miyagi Prefecture, where there were 9382 fatalities, 2431 people missing, and 3792 people injured. By comparison, the Great Hanshin-Awaji Earthquake of 1995 left 6308 dead, 3 people missing, and 43117 people injured. ${ }^{2}$ The morbidity/ mortality ratio was 0.28 in the recent Great Eastern Japan Earthquake and 6.84 in the Great Hanshin-Awaji Earthquake. The extremely small number of injuries, as compared with the number of people dead and missing, is the hallmark of a tsunami disaster.

Four hours after the earthquake, 4 physicians, 1 nurse, and 2 administrative workers with Japan Disaster Medical Assistance Team (DMAT) $)^{3}$ certification were sent from Tokyo Medical and Dental University to the most heavily damaged area, Miyagi Prefecture. We reached Sendai City in Miyagi Prefecture at 4 AM on March 12 and provided hospital support at Sendai Medical Center, the prefecture's largest disaster-base hospital. At that time, 25 DMATs composed of approximately 130 people had assembled at that hospital. Of those teams, 18 provided support in 6-hour rotating shifts in the hospital's emergency department, 5 worked on site at a rescue command post in the tsunami-stricken region along the coast, and 2 worked at the staging care unit set up at the Self-Defense Force's Kasuminome base. By the night of March 13, another 52 DMATs had assembled at Sendai Medical Center (Figure).

The emergency department support teams were divided to serve at a triage post at the hospital entrance, and another team cared for those being prepared for transport to remote locations outside of the disaster area. Our team served as the lead team of the red area. Table 1 shows the categories and colors of triage in Japan. Sendai Medical Center sustained only minor structural damage due to the earthquake, but had to rely on its own power generator for electricity due to widespread power outages throughout Sendai. Computed tomography scanners could not be used, and only some of the medical equipment, such as basic $\mathrm{x}$-ray machines and

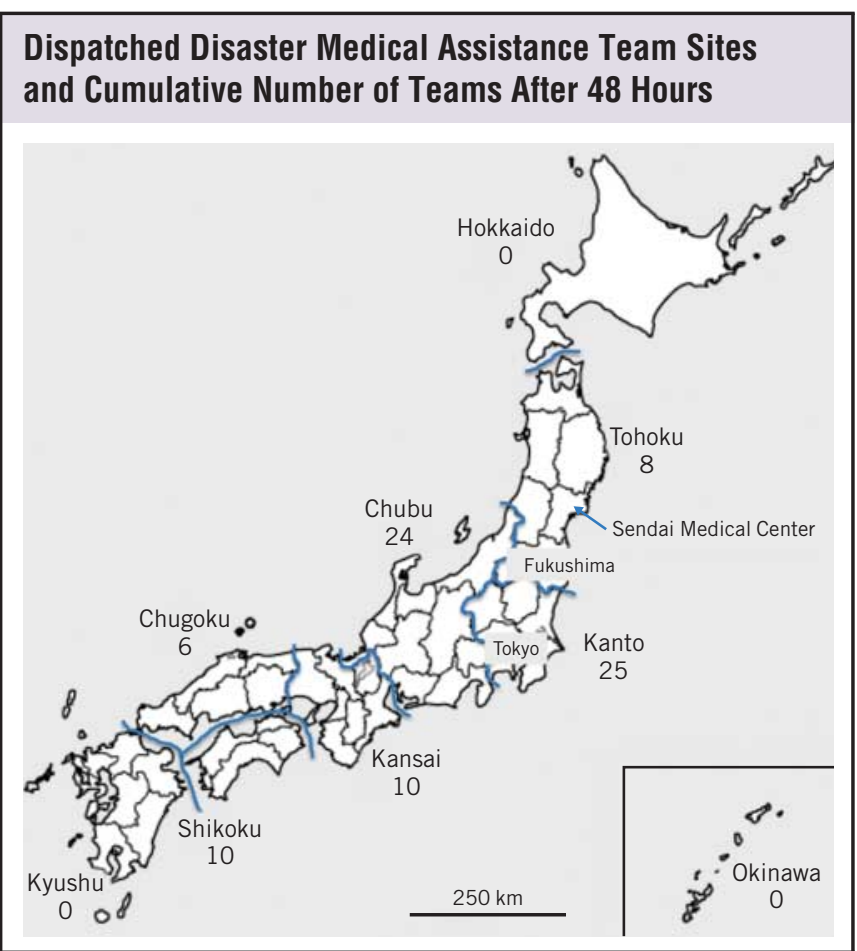

\section{TABLE 1}

\begin{tabular}{|c|c|}
\hline Category/Color (Meaning) & Consequences \\
\hline I/Red (Immediate) & $\begin{array}{l}\text { Used for viable victims with } \\
\text { potentially life-threatening conditions }\end{array}$ \\
\hline II/Yellow (Observation) & $\begin{array}{l}\text { Used for victims with } \\
\text { non-life-threatening injuries, but who } \\
\text { urgently require treatment }\end{array}$ \\
\hline III/Green (Wait) & $\begin{array}{l}\text { Used for victims with minor injuries } \\
\text { who do not require ambulance } \\
\text { transport }\end{array}$ \\
\hline 0/Black (Dead) & $\begin{array}{l}\text { Used for victims who are dead, or } \\
\text { whose injuries make survival unlikely }\end{array}$ \\
\hline
\end{tabular}

emergency blood testing equipment, could be operated. Some of the operating rooms were still functional, but only minor surgical procedures could be performed. The vast majority of the hospital staff assembled at the hospital and worked without sleep from the time the disaster struck.

Table 2 shows the number of patients that came to the hospital for emergency care. The period from the initial disaster until the next day, March 12, saw the peak arrival of critically injured patients. However, patients transported from isolated coastal communities located far from Sendai began coming in on March 14 and 15, creating a bimodal distribution of patients. Patients with injuries directly caused by the earthquake and tsunami, such as fractures of the pelvis, spinal cord injuries, and lower leg compartment syndrome, arrived at the hospital within 24 hours after the initial disas- 
TABLE 2

\begin{tabular}{|c|c|c|c|c|c|c|}
\hline \multicolumn{7}{|c|}{ Number of Victims at the National Sendai Medical Center } \\
\hline March 12 & 13 & 50 & 81 & 0 & 144 & 44 \\
\hline March 13 & 7 & 30 & 78 & 0 & 115 & 28 \\
\hline March 14 & 10 & 55 & 87 & 0 & 152 & 43 \\
\hline March 17 & 7 & 14 & 25 & 0 & 46 & 21 \\
\hline Total No. & 70 & 247 & 431 & 3 & 751 & 230 \\
\hline
\end{tabular}

ter. The vast majority of these patients were also affected by hypothermia as a result of having been exposed to the elements while waiting for rescue. After the first 24 hours, the majority of patients suffered from diseases incurred after evacuation.

Tomohisa Shoko, MD

Yasuhiro Otomo, MD

Atsushi Shiraishi, MD

Yutaka Ueki, MD

Author Affiliations: Tokyo Medical and Dental University Hospital of Medicine, Shock Trauma and Emergency Medical Center, Tokyo, Japan.
Correspondence: Tomohisa Shoko, MD, Tokyo Medical and Dental University Hospital of Medicine, Shock Trauma and Emergency Medical Center, 1-5-45 Yushima, Bunkyouku, Tokyo, Japan 113-8519 (e-mail: shouaccm@tmd.ac.jp).

\section{REFERENCES}

1. Yoshinaga K. The Role of Social Media in Japan During Natural Disasters. April 20, 2011. http://www.npa.go.jp/archive/keibi/biki/higaijokyo.pdf. Accessed August 7, 2011.

2. Ukai T. The Great Hanshin-Awaji Earthquake and the problems with emergency medical care. Ren Fail. 1997;19(5):633-645.

3. Kondo H, Koido Y, Morino K, et al. Establishing disaster medical assistance teams in Japan. Prehosp Disaster Med. 2009;24(6):556-564. 